\title{
PRAKTEK KOMERSIALISASI LEMBAGA KEUANGAN MIKRO SYARIAH DALAM PANDANGAN ETIKA BISNIS ISLAM
}

\author{
Andriyani Hapsari ${ }^{1)}$
}

${ }^{2)}$ dosen universitas pamulang, email: andriyani hapsari@yahoo.com

\section{ARTICLES}

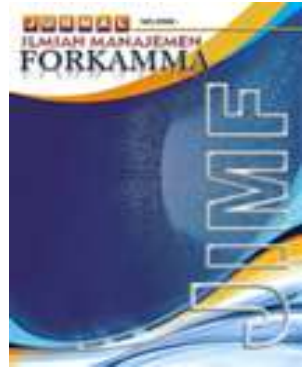

\section{JURNAL ILMIAH MANAJEMEN FORKAMMA}

Vol.2, No.1, November 2018 Halaman : $57-72$

(C) LPPM \& FORKAMMA

Prodi Magister Manajemen UNVERSITAS PAMULANG

ISSN (online) : 2599-171X

ISSN (print) : :2598-9545

Keyword :

Microfinance,

Commercialization, Islamic

Business Ethics

JEL. classification :

G21 O18 R51

\section{Contact Author :}

PRODI
MAGISTER MANAJEMEN \&
FORKAMMA UNPAM
JL.Surya Kencana No.1 Pamulang
Tangerang Selatan - Banten
Telp. (021) 7412566, Fax (021) 7412491
Email :
uurnalforkamma.unpam@gmail.com

Tujuan penelitian ini untuk : (1) mengetahui secara mendalam praktek komersialisasi dalam keuangan mikro, dan (2) menganalisis praktek komersialisasi dari sudut pandang etika bisnis Islam. Penelitian ini menggunakan pendekatan normatif yang menggunakan tinjauan ekonomi syariah untuk menilai praktek komersialisasi dalam keuangan mikro. Jenis penelitian yang digunakan adalah penelitian kualitatif yang tidak menggunakan perhitungan matematis dan statistic, dan dengan metode analisis deskriptif. Hasil penelitannya adalah : (1) Komersialisasi dalam keuangan mikro tidak sepenuhnya bertentangan dengan etika Bisnis Islam. (2) Konsep komersialisasi itu sendiri bersifat kontraproduktif dalam mencapai misi social dan bisnis sekaligus. (3) Nilai moral dalam etika bisnis Islam justru akan mampu mewujudkan lembaga keuangan mikro syariah sebagai institusi pengentasan kemiskinan yang juga mampu meraih keuntungan wajar sebagai institusi bisnis.

The purpose of this study is to: (1) know in depth the practice of commercialization in microfinance, and (2) analyze the practice of commercialization from the standpoint of Islamic business ethics. This study uses a normative approach that uses Islamic economic review to assess the practice of commercialization in microfinance. The type of research used is qualitative research that does not use mathematical and statistical calculations, and with descriptive analysis methods. The results of the research are: (1) Commercialization in microfinance is not completely contrary to Islamic business ethics. (2) The concept of commercialization itself is counterproductive in achieving social and business missions at once. (3) Moral values in Islamic business ethics will actually be able to realize microfinance institutions as poverty alleviation institutions that are also able to achieve reasonable profits as business institutions. 


\section{A. Pendahuluan}

Komersialisasi lembaga keuangan mikro merupakan suatu dorongan terhadap lembaga keuangan mikro untuk menyalurkan pinjaman setara dengan harga pasar, tidak lagi bergantung pada dana subsidi, menghimpun dana komersial, dan berorientasi profit. Hal ini dilakukan untuk menjaga kesinambungan lembaga dalam memberikan layanan keuangan.

Komersialisasi ini mendapat kritikan yang menyentuh pada tiga hal dasar, pertama adanya orientasi terhadap keuntungan (profit) yang berlebihan, akan mendorong lembaga keuangan mikro mengenakan suku bunga yang tinggi, sehingga mencegah calon peminjam mengambil pinjaman dari lembaga tersebut. Kedua komersialisasi keuangan mikro akan mendesak lembaga keuangan mikro untuk tidak lagi memberikan layanan kepada masyarakat miskin. Karena memberikan pelayanan kepada yang lebih baik tingkat ekonominya akan lebih memberikan keuntungan. Kritik yang ketiga, menyoroti masalah etika. Karena pada akhirnya dapat dilihat bahwa keuntungan lembaga keuangan mikro justru berasal dari kaum miskin. Lembaga keuangan mikro tumbuh dari laba ditahan, artinya sebagian kelompok orang miskin memberikan pembiayaan kepada kaum miskin yang lain. Jika keuntungan ini juga dinikmati oleh pemilik lembaga keuangan mikro, maka semakin tidak bisa diterima secara etika.(Lutzenkirchen \&Weistroffer : 2012).

Komersialisasi lembaga keuangan mikro juga dipandang sebagai alat pembangunan ekonomi yang kental dengan pengaruh paham neoliberalisme. Komersialisasi dinilai mengurangi dan meminimalisir campur tangan pemerintah dalam menyelesaikan masalah kemiskinan dan menyerahkannya kepada mekanisme pasar. Sumber dana lembaga keuangan mikro tidak lagi berupa dana hibah, bantuan dan subsidi dari pemerintah melainkan murni dana komersial baik dari tabungan sukarela, pinjaman, serta modal investasi.

Di Indonesia, industri keuangan mikro syariah mulai bangkit pada tahun 1990-an. Diawali dan diprakarsai oleh beberapa ormas Islam sebagai bentuk respon akan adanya kebutuhan terhadap layanan keuangan untuk masyarakat miskin yang sesuai syariah. Inisiatif pendirian lembaga yang berasal dari lembaga non pemerintah dapat mengindikasikan bahwa lembaga keuangan mikro syariah beroperasi secara komersial. Pada tahun 2012 Perhimpunan BMT Indonesia - salah satu assosiasi BMT yang diprakarsai oleh LAZ Dompet Dhuafa mencatat terdapat 560 BMT yang terhimpun dalam jaringannya dengan total simpanan anggota Rp. 4.302 milyar.

Lalu bagaimana komersialisasi ini dipandang dari sudut etika bisnis Islam. Menjadi lembaga yang bisa bekerja secara professional dan mampu memberikan layanan keuangan secara berkelanjutan merupakan hal yang baik dan sesuai dengan syariat Islam. Seperti yang disampaikan Rasulullah dan diriwayatkan oleh Baihaqi bahwa "Sesungguhnya Allah mencintai seseorang jika ia beramal dengan suatu amalan atau pekerjaan maka ia kerjakan dengan itqon" Itqon merupakan sifat Allah yang senantiasa melazimi dalam seluruh penciptaannya. Allah berfirman dalam Al Qur'an surat An Naml ayat 88 yang artinya "Begitulah penciptaan Allah yang membuat dengan (Itqon) kokoh tiap-tiap sesuatu. Sesungguhnya Allah Maha Mengetahui apa yang kalian kerjakan."

Begitu pula dalam hal penentuan harga (pricing), Islam menyerahkannya dalam mekanisme pasar yang alami. Tertuang dalam Hadits dari Rasulullah SAW yang pada suatu saat diminta oleh para sahabat untuk menentukan harga-harga yang sedang melonjak. Rasulullah menjawab "Sesungguhnya Allah-lah yang menentukan harga, yang 
mencabut, yang membentangkan, dan yang memberi rezeki. Saya sungguh berharap dapat bertemu Allah dalam keadaan tidak seorang pun dari kalian yang menuntut kepadaku karena kezaliman dalam darah dan harta" (HR. Ahmad, Abu Daud, Tirmidzi, Ibnu Majah, Darami, dan Abu Yakla)

Lembaga keuangan mikro di Indonesia selalu dianggap sebagai instrument pembangunan ekonomi yang ampuh untuk mengentaskan kemiskinan. Akan tetapi perlu pembahasan lebih lanjut, apakah memang komersialiasasi sudah sesuai dengan cita-cita dan pesan moral dari system keuangan Islam. Jika beroperasi secara komersial bagaimana menjalankan misi sosialnya mengentaskan kemiskinan. Membahas arah kebijakan, perkembangan, serta kritik terhadap industry keuangan mikro dari sudut pandang etika bisnis Islam, diharapkan mampu memberikan pandangan yang lebih objekif. Oleh karena itu, tujuan dari penelitian ini adalah (1) mengetahui secara mendalam praktek komersialisasi dalam keuangan mikro, (2) menganalisis praktek komersialisasi dari sudut pandang etika bisnis Islam.

\section{B. Metodologi Penelitian}

Jurnal penelitian ini menggunakan pendekatan normatif yang menggunakan tinjauan ekonomi syariah untuk menilai praktek komersialisasi pada lembaga keuangan mikro syariah. Jenis penelitian yang digunakan adalah penelitian kualitatif yang tidak mengadakan penghitungan matematis dan statistik. Data diperoleh melalui penelitian kepustakaan yaitu mengumpulkan dan mempelajari data dan bahan dari berbagai sumber kepustakaan meliputi buku, skripsi, tesis, jurnal penelitian terdahulu, laporan konferensi, laporan program bantuan lembaga pembangunan dan lembaga donor, internet, dan media lainnya yang ada yang berkaitan dengan masalah pokok. Penulis menggunakan metode analisis deskriptif, penulis membaca, mempelajari, memahami dan kemudian menguraikan semua data yang diperoleh untuk membuat analisa yang komprehensif sesuai dengan tujuan penelitian.

\section{Komersialisasi Keuangan Mikro, Sejarah dan Latar Belakangnya}

Sebelum tahun 1970-an kelompok masyarakat miskin dikategorikan sebagai unbankable, yaitu kelompok masyarakat yang tidak tersentuh oleh layanan perbankan karena dinilai tidak layak. Namun begitu, sesungguhnya konsep keuangan mikro yang memberikan layanan keuangan kepada kaum miskin bukan merupakan sesuatu yang hal yang baru. Sejak tahun 1700-an sudah hadir berbagai bentuk layanan keuangan untuk kaum miskin dalam bentuk informal.

CGAP (The Consultative Group to Assist The Poor) dalam makalah pelatihannya menyampaikan bahwa ada enam tahapan dalam evolusi keuangan mikro. Pertama, periode informal pada awal abad ke 15. Layanan simpanan dan koperasi pada masa ini masih dalam bentuk informal seperti arisan di Indonesia. Tahapan yang kedua adalah gerakan credit union. Dipelopori oleh Friedrich Wilhelm Raiffeissen, gerakan ini memberikan layanan keuangan kepada masyarakat miskin pada pertengahan abad ke 18. Dan kemudian gerakan ini menyebar ke negara-negara lain di Eropa dan Amerika Utara.

Selanjutnya tahapan ketiga yaitu tahapan koperasi formal atau bank rakyat seperti BRI dan BPR di Indonesia yang dibuka pertama kali pada tahun 1895. Tahapan keempat berlangsung antara tahun 1950-1970 dimana pemerintah banyak memberikan kredit pertanian dan agrikultur melalui bank pemerintah. Kredit diberikan bertujuan untuk meningkatkan produktifitas petani kecil. Pada tahapan ini banyak program yang 
mengalami kegagalan. Selanjutnya adalah tahapan kelima berlangsung pada tahun 1970an, dimana layanan keuangan mikro banyak diberikan oleh Lembaga Swadaya Masyarakat. Era ini ditandai dengan suksesnya Grameen Bank di Bangladesh. Pada era ini mayoritas layanan keuangan yang diberikan adalah kredit. Dan yang terakhir adalah tahap keenam system keuangan inklusi, yaitu menyatukan layanan keuangan bagi orang miskin ke dalam system keuangan.

Visi dari system keuangan inklusi ini adalah terciptaya dunia dimana masyarakat miskin yang berada di dalamnya bisa mendapatkan akses permanen terhadap layanan keuangan yang berkualitas, melalui berbagai tipe institusi (CGAP, 2006 : viii). Senada dengan itu dalam Strategi Nasional Keuangan Indonesia (Sekretariat Wakil Presiden RI, 2012 : 6) dinyatakan bahwa visi keuangan inklusi adalah mencapai suatu system keuangan yang bisa diakses oleh seluruh lapisan masyarakat untuk mempromosikan pertumbuhan ekonomi, pengentasan kemiskinan, dan pemerataan pendapatan di Indonesia. Akses keuangan permanen yang dimaksudkan bukan hanya kredit, melainkan tabungan, asuransi, dan produk keuangan lainnya.

Meningkatkan akses keuangan kepada kaum miskin diharapkan bisa memutus lingkaran setan kemiskinan. Dalam teori lingkaran setan kemiskinan (The Vicious of Poverty) yang disampaikan oleh Ekonom Ragnar Nurkse bahwa terdapat dua factor yang mempengaruhi lingkaran setan kemiskinan. Pertama, sisi penawaran lingkaran setan kemiskinan, bahwa pada Negara miskin produktivitasnya sangat rendah sehingga tidak cukup untuk pembentukan modal. Hal ini bisa dijelaskan bahwa tingkat produktivitas yang rendah mengakibatkan tingkat pendapatan yang rendah, kemudian kemampuan masyarakat untuk menabung juga menjadi rendah yang pada akhirnya membuat pembentukan modal rendah juga. Dan Negara pun akan menghadapi kekurangan barang modal dan produktivitas akan tetap rendah.

Kedua dari sisi permintaan, bahwa rangsangan untuk investasi rendah karena kecilnya kemampuan beli masyarakat, dimana hal tersebut diakibatkan karena rendahnya pendapatan riil, yang disebabkan oleh produktivitas yang rendah. Rendahnya produktivitas bagaimana pun juga merupakan hasil dari sedikitnya modal yang digunakan untuk produksi yang pada akhirnya disebabkan oleh rendahnya rangsangan untuk melakukan investasi.

Lingkaran setan kemiskinan inilah yang ingin diputus oleh pertumbuhan sector keuangan yang dapat menjangkau masyarakat miskin, yaitu melalui system keuangan inklusi. Semakin meningkatnya akses layanan keuangan kepada kaum miskin maka jumlah penduduk miskin dapat dikurangi. Seperti yang disampaikan oleh Ari dan Galuh dalam penelitiannya tentang pengaruh pertumbuhan ekonomi dan sector keuangan terhadap pengurangan kemiskinan di Indonesia bahwa pertumbuhan sector keuangan yang terjadi pada 1 periode sebelumnya memiliki pengaruh terhadap pengurangan pertumbuhan kemiskinan, walaupun pengaruhnya tersebut tidak signifikan ${ }^{1}$ Penelitan ini menggunakan rasio jumlah uang yang beredar dalam arti luas (M2) terhadap PDB. M2 dalam penelitian tersebut meliputi uang kartal, uang giral, deposito berjangka, dan tabungan. Variabel ini menunjukan kedalaman sector keuangan secara riil pada perekonomian yang sedang mengalami pertumbuhan, di mana sector keuangan menyediakan jasa untuk transaksi maupun menerima tabungan dari masyarakat.

\footnotetext{
${ }^{1}$ Pengaruh Pertumbuhan Ekonomi dan Pertumbuhan Sektor Keuangan Terhadap Pengurangan Kemiskinan di Indonesia, Ari Mulianta Ginting, Galuh Prila Dewi, P3DI Bidang Ekonomi dan Kebijakan Publik, 31 Desember 2013
} 
Pada tahap system keuangan inklusi ini, lembaga keuangan mikro didorong untuk bisa menjadi lembaga yang kuat agar bisa memberikan layanan keuangan secara berkesinambungan dan meraih masyarakat miskin yang lebih banyak lagi. Oleh karena itu diterapkanlah strategi komersialisasi dimana lembaga keuangan mikro didorong menjadi lembaga yang berorientasi profit dan mampu mengundang investasi eksternal

Konsep komersialisasi ini juga lahir sebagai hasil dari proses pembelajaran atas pengalaman yang diperoleh selama dalam tahapan evolusi keuangan mikro yang disebutkan di atas. Dimana pada saat banyak program pembangunan di negara berkembang menerapkan konsep keuangan mikro dengan memberikan kredit kepada petani kecil justru banyak mengalami kegagalan. Kredit yang disubsidi dari pemerintah, dan disalurkan dibawah harga pasar, ternyata justru menimbulkan permasalahan ketergantungan lembaga terhadap dana hibah, menghasilkan inefisiensi, menghambat pertumbuhan, serta mengakibatkan keengganan mencari sumber dana baru seperti tabungan masyarakat dan dana komersial lainnya (Lutzenkirchen \& Weistroffer : 2012) . Ditambah lagi dengan latar belakang pemikirin neo liberal dalam ekonomi dan politik serta hasil pengamatan bahwa masyarakat miskin mau membayar harga pinjaman yang mahal kepada rentenir (Lutzenkirchen \& Weistroffer : 2012). Maka lembaga keuangan mikro didorong untuk menyalurkan pinjaman setara dengan harga pasar, tidak lagi bergantung pada dana subsidi, menghimpun dana komersial, dan berorientasi profit.

Menurut Stephanie Charitonenko dan Ismah Afwan dalam bukunya Commercialization of Microfinance - Indonesia, komersialiasai lembaga keuangan mikro meliputi

a. Mengadopsi pendekatan bisnis profesional ke dalam administrasi dan operasional lembaga keuangan mikro. Seperti misalnya mengembangkan diversifikasi, mengembangkan produk lembaga keuangan mikro yang didorong oleh permintaan pasar dan menerapkan tingkat suku bunga yang mampu menutupi biaya

b. Menuju kemandirian keuangan dan operasional dengan meningkatkan pemulihan biaya dan efisiensi, serta mempeluas jangkauan

c. Menggunakan sumber dana komersial, contohnya pinjaman non subsidi dari lembaga apex (institusi pemberi pinjaman kepada lembaga keuangan mikro) atau bank komersial, menghimpun tabungan sukarela, atau sumber pendanaan lainnya.

d. Beroperasional sebagai lembaga keuangan formal yang berorientasi pada profit, yang menerapkan peraturan dan prinsip kehati-hatian dan supervisi, sehingga mampu menarik investasi modal.

\section{Kritik Terhadap Komersialisasi Pada Keuangan Mikro}

Walaupun banyak penelitian yang menyatakan keberhasilan komersialisasi keuangan mikro untuk mengentaskan kemiskinan, namun dari sudut pandang ekonomi pembangunan masih perlu pembuktian lebih lanjut mengenai dampak bagi usaha pengentasan kemiskinan. Kritik terhadap komersialisasi keuangan mikro menyentuh tiga hal dasar, pertama adanya orientasi terhadap keuntungan (profit) yang berlebihan, akan mendorong lembaga keuangan mikro mengenakan suku bunga yang tinggi, sehingga mencegah masyarakat miskin sebagai calon peminjam untuk mengambil pinjaman dari lembaga tersebut. Kedua komersialisasi keuangan mikro akan mendesak lembaga keuangan mikro untuk tidak lagi memberikan layanan kepada masyarakat miskin. Karena memberikan pelayanan kepada yang lebih baik tingkat ekonominya akan lebih memberikan keuntungan. Kritik yang ketiga, menyoroti masalah etika. Karena pada akhirnya dapat dilihat bahwa keuntungan lembaga keuangan mikro justru berasal dari kaum miskin. Lembaga keuangan mikro akan tumbuh dari laba yang ditahan, artinya sebagian kelompok orang miskin memberikan pembiayaan kepada kaum miskin yang 
lain. Jika keuntungan ini juga dinikmati oleh pemilik lembaga keuangan mikro, maka semakin tidak bisa diterima secara etika. (Lutzenkirchen \& Weistroffer : 2012)

Milford Bateman dalam penelitiannya melihat komersialisasi lembaga keuangan mikro sebagai produk pemikiran neoliberalisame. Disebutkan, bahwa sejak tahun 1980an subsidi yang diberikan kepada lembaga kredit mikro dari lembaga donor, pemerintah dan lembaga lainnya tidak boleh lagi dilakukan. Bahwa setiap lembaga harus sampai ke pada kondisi mampu menutupi biayaanya secara penuh (full cost recovery). Model kredit mikro yang digerakan oleh pasar (market driven) kemudian menjadi kebijakan pembangunan internasional yang penting. Dukungan sumberdaya dan teknis diberikan untuk membantu terlaksananya transformasi keuangan mikro. Tercatat secara simultan, model program dukungan keuangan yang lain seperti dukungan keuangan untuk UKM ditutup. Dan sasaran selanjutanya adalah privatisasi air, pendidikan, dan kesehatan. Kredit mikro disini berfungsi untuk menyediakan uang tunai kepada masyarakat miskin untuk bertransaksi akibat privatisasi tersebut (Bateman:2014) ${ }^{2}$

Salah satu daya tarik program keuangan mikro bagi neoliberalis adalah melihat keberhasilan Grameen Bank dalam memberikan layanan keuangan kepada kaum miskin tanpa dukungan keuangan dari Negara. Ide yang kemudian muncul adalah seluruh lembaga keuangan mikro harus mampu untuk bertahan hidup dan memperoleh penghasilan dari pasar. Keuangan mikro juga dapat digunakan untuk melemahkan konsep penyediaan pelayanan dasar oleh Negara dan mendukung privatisasi oleh sektor swasta. Layanan kebutuhan dasar masyarakat seperti pendidikan, kesehatan, air, dan sanitasi secara perlahan dikurangi subsidinya dari Negara dan diprivatisasi oleh pihak swasta. Keuangan mikro kemudian menjadi "penyelamat" bagi masyarakat miskin untuk dapat mengakses layanan dasar tersebut melalui pinjaman mikro.

Bateman dalam penelitiannya yang lain menyampaikan bahwa kelemahan program pengentasan kemiskinan melalui keuangan mikro antara lain adalah, pertama mengacuhkan skala ekonomi usaha mikro dan kecil yang menjadi nasabahnya. Bahwa setiap usaha atau perusahaan memiliki batas minimum skala produksi efisien, yang apabila tidak terpenuhi maka akan mustahil usaha tersebut dapat bertahan hidup. Banyaknya program keuangan mikro akan mendorong lahirnya usaha mikro dan kecil baru pada satu lokasi dalam jumlah yang banyak. Hal ini mengakibatkan inefisiensi mengingat ukuran pasar yang tidak berubah, permintaannya tetap namun di sisi supply bertambah. Sehingga skala usaha mikro dan kecil tidak bisa tumbuh dan berkembang. Karnarni (2007:39) melaporkan bahwa kurangnya skala ekonomi pada sector usaha mikro secara serius merusak potensi pertumbuhan ekonomi India. Ukuran rata-rata usaha mikro di India adalah kurang dari sepersepuluh ukuran usaha di Negara berkembang lainnya. Dukungan pada keuangan mikro dan penciptaan usaha mikro akan mengakibatkan hal ini menjadi lebih buruk.

Kelemahan yang kedua adalah merupakan kelanjutan dari point yang pertama. Ketika keuangan mikro mengacuhkan skala ekonomi usaha mikro hal ini akan mengakibatkan masalah pada komposisi ekonomi lokal. Sektor informal yang menjadi sasaran utama keuangan mikro dipaksa untuk menyerap jumlah usaha mikro yang tidak terbatas. Ekonomi local secara cepat menjadi jenuh atas jumlah usaha mikro yang terus berambah. Idealnya usaha mikro bisa segera tumbuh dan berkembang menjadi sektor formal. Namun dengan terus tumbuhnya usaha mikro baru menyulitkan hal tersebut bisa terjadi. Keuangan mikro membantu untuk menurunkan pendapatan, gaji, keuntungan dan

\footnotetext{
${ }^{2}$ The Rise and Fall of Muhammad Yunus and The Microcredit Model. Saint Mary University
} 
kondisi kerja atau kondisi hidup suatu masyarakat di Negara berkembang dan transisi, serta sangat tampak pada daerah yang dominan dengan wilayah miskin perkotaan (lihat Breman dan Das, 2000; Breman, 2003; Davis, 2006). Bateman (tanpa tahun:11) menyampaikan apa yang terjadi di Bangladesh sebagai "rumahnya keuangan mikro" memperlihatkan sesuatu yang mengkhawatirkan, sektor informal mendominasi ekonomi di kota-kota besar. Sebagai contoh, lebih dari $63 \%$ populasi pekerja di ibukota Dhaka saat ini berada di sektor informal (UN Habitat 2003:103). Masyarakat Bangladesh bahkan ada yang mengalami hal yang lebih buruk, yaitu ketika gagal dalam usahanya mereka harus tetap membayar pinjamannya sehingga harus membayar dengan menjual asset keluarganya atau harus mengalami overindebtedness, yaitu suatu kondisi dimana individu mengalami kelebihan hutang untuk melunasi hutangnya yang terdahulu. Dan hal tersebut bisa menciptakan kemiskinan yang lebih buruk dibandingkan sebelumnya.

Ketiga, keuangan mikro tidak mendukung usaha kecil yang memiliki prospek dalam meningkatkan pengusaan teknologi. Padahal untuk mengurangi kemiskinan, suatu Negara berkembang perlu memiliki penguasaan yang baik terhadap teknologi yang berkaitan dengan proses produksi dan manufaktur. Pada kenyataannya keuangan mikro hanya membantu usaha mikro dan kecil yang sangat sederhana yang bisa membayar kembali pinjaman dan bunganya yang mahal dalam waktu yang singkat. Artinya keuangan mikro tidak bisa digunakan untuk mendukung peningkatan industry di Negara berkembang. Dan hal ini sangat disayangkan ketika dana-dana pembangunan yang tadinya digunakan untuk mendukung pertumbuhan industrialisasi harus dialihkan ke keuangan mikro.

Keempat, keuangan mikro tidak mempedulikan kebutuhan untuk mempromosikan konektibilitas vertical dan horizontal. Koneksi horizontal yang dimaksud disini adalah jaringan dan clustering, dan koneksi vertical adalah jaringan subkontrak. Dimana kedua koneksi ini merupakan hal yang penting untuk menjamin keberlanjutan dan pertumbuhan ekonomi local. Point keempat ini berkaitan dengan point-point sebelumnya, yaitu ketika keuangan mikro mendorong lahirnya usaha-usaha mirko mendukung produktivitasnya. Begitu pula ketika keuangan mikro tidak mampu mendukung penguasaan teknologi pada usaha kecil, maka koneksi vertical tidak akan terbentuk. Perusahaan besar tidak bisa mendapatkan supplier dari usaha kecil local untuk mendukung produktivitasnya Karen tidak adanya kemampuan usah kecil untuk memproduksi komponen yang dibutuhkan perusahaan besar. Yang pada akhirnya perusahaan besar harus mengimpor dari luar daerahnya.

Kelemahan kelima merupakan kecil yang baru maka koneksi horizontal tidak akan terwujud. Karena sektor informal ini tidak terlalu membutuhkan koneksi horizontal atau kerjasama antar usaha mikro yang berarti untuk efek dari kelemahan-kelemahan yang telah dijelaskan sebelumnya, yaitu program keuangan mikro mengakibatkan ketergantungan ekonomi local kepada impor barang dari luar. Runtuhnya sektor manufaktur dan produksi agrikultur lokal terpaksa digantikan dengan perdagangan instan dan dibanjiri produk impor.

Kemudian yang keenam, komerasialisasi keuangan mikro pada akhirnya mengakibatkan lemahnya solidaritas social, kepemilikan dan kontrol komunitas lokal. Seperti disampaikan oleh Leys (2001) Ketika aktivitas pemberdayaan masyarakat dan pengentasan kemiskinan dipaksa bersifat komersil dan berorientasi keuantungan secara bersamaan akan meningkatkan kemungkinan berkurangnya solidaritas local, komunikasi interpersonal, kesukarelawanan, dan interaksi yang berdasarkan kepercayaan. Termasuk pada kasus pinjaman kelompok perempuan yang sering diklaim mampu membangun modal social dan solidaritas di komunitas, namun sebenarnya menumbuhkan tekanan 
social dan tendensi untuk mempermalukan pelaku telat bayar, yang pada akhirnya merusak modal social atau solidartas social dalam masyarakat.

\section{E. Praktek Komersialisasi Lembaga Keuangan Mikro Syariah Dalam Pandangan Etika Bisnis Islam}

\subsection{Definisi Etika Bisnis Islam}

Berdasarkan kamus besar Bahasa Indonesia, etika adalah ilmu tentang apa yang baik dan apa yang buruk dan tentang hak dan kewajiban moral. ${ }^{3}$ Etika bisnis merupakan cara untuk melakukan kegiatan bisnis, yang mencakup seluruh aspek yang berkaitan dengan individu, perusahaan dan juga masyarakat. Etika bisnis dalam suatu perusahaan dapat membentuk nilai, norma dan perilaku karyawan serta pimpinan dalam membangun hubungan yang adil dan sehat dengan pelanggan/ mitra kerja, pemegang saham, dan masyarakat. ${ }^{4}$ Menurut Crane (2016:5) etika bisnis adalah sebuah studi mengenai benar dan salah dari penanganan situasi, kegiatan, dan keputusan bisnis.

Etika dan Hukum (law) keduanya sama-sama berbicara mengenai benar dan salah. Tapi Hukum merupakan merupakan bentuk kelembagaan dan kodifikasi etika menjadi peraturan sosial yang spesifik (Crane : 2016). Hukum bisa dikatakan sebagai standar minimum tindakan yang diterima oleh masyarakat, dan etika meliputi hal-hal yang lebih luas lagi. Sebagai contoh, di beberapa Negara tidak ada hukum yang melarang untuk melakukan pengetesan produk pada binatang, namun hal tersebut menjadi sebuah etika bisnis untuk tidak melakukannya.

Etika dibentuk oleh moralitas, yaitu hal-hal yang berkaitan dengan norma-norma, nilai-nilai, kepercayaan yang tertanam pada individu dan masyarakat yang pada proses selanjutnya akan membentuk kesepakatan mengenai mana yang benar dan mana yang salah.

Dalam Islam, istilah etika lebih sering dikenal dengan istilah akhlak. Selain itu Al Qur'an juga menggunakan sejumlah istilah yang menjelaskan konsep kebaikan, antara lain adalah khoir (kebaikan, goodness), birr (kebajikan, righteousness), qist (kewajaran, equity), 'adl (keseimbangan, equilibrium), keadilan (justice), haq (kebenaran, truth), ma'ruf (diketahui, diterima), serta takwa (kesalehan, piety) ${ }^{5}$

Islam telah menempatkan nilai etika atau akhlak pada tempat yang tinggi. Ditandai dengan diturunkannya Rasulullah SAW oleh Allah SWT sebagai teladan dalam rangka menyempurnakan akhlak umatnya. Seperti yang disebutkan dalam hadis Nabi "Sesungguhnya aku diutus hanya untuk menyempurnakan kemuliaan akhlak." (HR. Al Bayhaqi). Terdapat empat aksioma etika ekonomi dalam Islam yaitu tauhid, keseimbangan (keadilan), kebebasan, dan tanggung jawab (Naqvi : 2003). Tauhid atau prinsip keesaan terhadap Allah SWT, menjadi landasan yang membedakan ekonomi Islam dengan ekonomi kapitalis dan sosialis yang berdasarkan sekularisme dan materialism. Konsep Tauhid menjadikan manusia melakukan penyerahan tanpa syarat kepada kehendak-Nya sekaligus juga pengakuan terhadap eksistensi manusia yang dipersatukan dalam ketaatan kepada Allah semata. Hal ini menghasilkan seorang pelaku ekonomi akan melakukan aktivitasnya tidak semata-mata untuk mengejar keuantungan

\footnotetext{
${ }^{3}$ https://kbbi.web.id/etika

${ }^{4} \mathrm{https}: / /$ id.wikipedia.org/wiki/etika_bisnis

${ }^{5}$ Membongkar Konsep Etika Bisnis Dalam AI Qur'an : Perspektif Epistemologis, Ahmad Syukron, MEI, STAIN Pekalongan
} 
material. Tapi keuntungan dunia dan akhirat serta menghindari segala bentuk eksploitasi terhadap sesama manusia.

Keseimbangan (keadilan), prinsip ini mengantarkan manusia bahwa segala sesuatu diciptakan Allah dalam keadaan seimbang dan serasi. Al Qur'an pun menjadikan keadilan sebagai wujud dari kedekatan pada ketaqwaan. Seperti yang diwahyukan oleh Allah SWT dalam QS AI Maidah : 8 "Hai orang-orang yang beriman hendaklah kamu jadi orang-orang yang selalu menegakan (kebenaran) karena Allah, menjadi saksi dengan adil. Dan janganlah sekali-kali kebencianmu terhadap sesuatu kaum, mendorong kamu untuk berlaku tidak adil. Berlaku adillah, karena adil itu lebih dekat kepada takwa. Dan bertakwalah kepada Allah, sesungguhnya Allah Maha Mengetahui apa yang kamu kerjakan." Dalam aktivitas ekonomi, keadilan salah satunya diwujudkan dalam bentuk pemerataan pendapatan dan kekayaan. Dalam Al Qur'an Surat Al Hasyr : 7 "....agar harta itu jangan hanya beredar di antara orang-orang kaya saja di antara kamu..."

Kebebasan (free will) yang dimaksud disini adalah kebebasan berkehendak dan bertanggungjawab tanpa melepaskan prinsip tauhid dan keadilan. Merupakan sebuah pengakuan terhadap eksistensi manusia, mahluk berakal yang diilhami dua jalan yaitu kebaikan dan keburukan dan kemampuan untuk memilih di antara ke dua jalan itu. Kebebasan ini tentunya tidak mengalahkan kekuasaan dan kebesaran Allah yang bersifat mutlak. Dalam aktivitas ekonomi, konsep kebebasan dalam Islam lebih mengarah kepada kerja sama, bukan persaingan apalagi sampai mematikan usaha satu sama lain. Kalaupun ada persaingan, sifatnya dalam rangka melakukan kebaikan atau fastabiqul khoirot (Nawatmi : 2010)

Tanggungjawab (responsibility). Seperti yang diuraikan sebelumnya bahwa prinsip kebebasan dalam Islam merupakan kebebasan yang bertanggungjawab. Hal ini merupakan tuntutan bagi manusia baik secara individu maupun kolektif. Dalam tataran aktivitas ekonomi, tanggung jawab berwujud salah satunya dalam bentuk perilaku konsumsi yang tidak hanya tergantung pada penghasilannya sendiri melainkan harus mengacu pada keadilan karena adanya kesadaran atas tingkat penghasilan dan konsumsi anggota masyarakat yang lain yang tidak sama dengan dirinya.

Dalam Jurnal Balancing Ethical Responsibility Among Multiple Organizational Stakeholder : The Islamic Perspective (Bekun \& Badawi, 2005), disampaikan bahwa beberapa kriteria etika dalam Islam adalah Keadilan dan Keseimbangan, Kepercayaan serta Kebajikan. Keadilan dideskripsikan dalam Al Qur'an dengan kata Adl yang berarti persamaan dan keseimbangan. Islam sangat mendorong umatnya untuk berbuat adil. Selain itu, adil juga dideskripsikan sebagai melakukan sesuatu sesuai dengan proporsinya. As Siddiqui (2002) mendeskripsikan Keadilan sebagai memberi setiap orang dan setiap hal sesuai pada tempatnya.

Nilai etika yang kedua adalah kepercayaan (trust) atau yang dikenal dalam Islam sebagai sifat Amanah. Manusia merupakah khalifah yang diciptakan oleh Allah SWT, diberikan amanah (kepercayaan) untuk mengelola alam semesta. Untuk menjalankan amanahnya tersebut Allah memberikan modal berbagai kenikmatan untuk diolah, dimaintain sehingga dapat mewujudkan kesejahteraan di dunia dan di akhirat. Sebagai konsekuensinya, di hari akhir nanti setiap manusia akan dimintai pertanggung jawabannya atas apa yang telah ia lakukan untuk mengemban misi tersebut. Dengan perannya tersebut, maka manusia tidak diperbolehkan untuk saling menzalimi, melakukan eksploitasi terhadap alam semesta, terhadap sebagian umat manusia yang lain dalam rangka hanya untuk memuaskan keinginan segelintir orang. 
Nilai selanjutnya adalah kebajikan (benevolence) yang dalam ajaran Islam dikenal sebagai Ihsan. Ihsan ini didefinisikan sebagai perbuatan baik kepada orang lain yang dilakukan bukan karena kewajiban, melainkan beyond kewajiban. Insan ini lahir dari kecintaan umat manusia kepada Allah SWT. Manusia dapat memiliki sifat Ihsan, apabila dalam dirinya sudah tertanam nilai Iman dan Islam.

Perwujudannya, sifat Ihsan ini mendorong manusia untuk bekerja atau beramal secara baik bahkan melebihi baik atau sempurna. Karena manusia yang memiliki Ihsan, selalu merasa dilihat Allah SWT dalam setiap amalnya, dan karena kecintaannya pada Allah, maka ia akan selalu memberikan amalnya yang terbaik. Jadi setiap muslim bukan hanya dituntut untuk produktif beramal tapi juga melahirkan amal yang unggul

\subsection{Praktek Komersialisasi Lembaga Keuangan Mikro Syariah Dalam Pandangan Etika Bisnis Islam}

Untuk membahas praktek komersialisasi dari sudut pandang etika Islam, penulis menggunakan pendekatan pada empat pokok pelaksanaan komersialisasi pada lembaga keuangan mikro yaitu pertama, komersialisasi mengadopsi pendekatan orientasi bisnis profit dalam administrasi dan operasional, termasuk melakukan pengembangan produk yang didorong oleh permintaan pasar, dan menerapkan tingkat suku bunga yang mampu menutupi biaya. Kedua, komersialisasi mengarahkan lembaga kepada kemandirian keuangan dan operasional dengan meningkatkan pemulihan biaya dan efisiensi serta memperluas jangkauan. Kemudian yang ketiga adalah menggunakan sumber dana komersial, seperti pinjaman bank, menghimpun tabungan sukarela atau sumber pendanaan lainnya. Dan yang keempat mendorong lembaga keuangan mikro untuk beroperasional sebagai lembaga keuangan formal yang berorientasi profit, yang menerapkan peraturan dan prinsip kehati-hatian, sehingga mampu menarik investasi modal.

\subsubsection{Mengadopsi Pendekatan Orientasi Profit Dalam Administrasi dan Operasional Lembaga Keuangan Mikro.}

Dalam Islam, bekerja merupakan bentuk ibadah manusia kepada sang pencipta. Bekerja merupakan perwujudan rasa syukur manusia atas potensi yang sudah diberikan Allah SWT, hingga manusia bisa menunaikan tugasnya sebagai khalifah untuk memakmurkan bumi. Dalam Al Qur'an surat Al A'raf ayat 10 : "Kami telah menjadikan untukmu semua di dalam bumi itu sebagai lapangan mengusahakan kehidupan (bekerja); Tetapi sedikit sekali diantaramu yang bersyukur." Dan Rasulullah pernah bersabda : "Pekerjaan terbaik adalah usahanya seseorang dengan tangannya sendiri dan semua jual-beli itu baik" (HR. Ahmad, Baihaqi, dll)

Lebih dari itu Islam memotivasi umatnya bukan hanya sekedar bekerja, tapi bekerja secara professional dan bersungguh-sungguh menjaga kualitas pekerjaannya. Etika kerja Islam menganggap bertanggung jawab terhadap pekerjaan merupakan suatu bentuk kebajikan. Dalam hadits, Rasulullah menasihati para sahabat yang mempunyai pekerjaan sebagai pedagang "Pedagang yang lurus dan jujur kelak akan tinggal bersama para nabi, shiddiqin, dan syuhada." (HR. Tirmidzi dan Al Hakim). Sedangkan bagi yang bekerja sebagai petani dan tukang kebun, beliau bersabda "Setiap muslim yang 

manusia atau binatang, maka ia itu dianggap telah bersedekah."

Memperoleh keuntungan dalam suatu usaha dengan cara yang jujur dan adil merupakan bagian dari bentuk profesionalitas kerja. Keuntungan diperlukan untuk menutupi biaya dan menjamin keberlanjutan usaha. Pada praktek komersialisasi, untuk memperoleh keuntungan, lembaga keuangan mikro didorong untuk melakukan diversifikasi produk yang sesuai dengan permintaan pasar, yaitu melakukan inovasi produk yang sesuai dengan kebutuhan rakyat miskin tapi tetap harus memberikan keuntungan bagi lembaga melalui penetapan suku bunga pinjaman untuk menutupi biaya operasional.

Untuk bisa memenuhi kebutuhan masyarakat miskin, produk keuangan harus memperhatikan beberapa hal yaitu pertama, arus uang masuk dan uang keluar masyarakat miskin memiliki durasi yang pendek karena harus berurusan dengan kebutuhan hidup sehari-hari. Uang yang diperoleh hari ini, bisa jadi sudah harus dibelanjakan untuk makan esok hari. Kedua produk keuangan harus mampu berurusan dengan kondisi darurat yang mungkin muncul tiba-tiba seperti gagal panen, sakit, kematian pencari nafkah, ataupun kecelakaan. Dimana hal tersebut dapat mempengaruhi kemampuan membayar pinjaman kembali. Ketiga, masyarakat miskin merupakan kelompok masyarakat yang harus berjuang keras untuk mengumpulkan uangnya untuk membiayai siklus hidup utama mereka seperti membiayai pernikahan, melahirkan anak, menyekolahkan anak, membiayai usaha kecilnya serta juga membangun asset rumah tangganya.

Dalam ekonomi Islam dikenal adanya konsep distribusi pendapatan dan distribusi kekayaan yang adil. Islam mengakui pendapatan dan kekayaan adalah hak milik pribadi namun tidak bisa mengalahkan kepemilikan mutlak Allah SWT yang telah mengamanahkan kekayaan tersebut kepada manusia untuk digunakan sebagai sumber daya untuk memakmurkan bumi. Artinya tidak dibenarkan jika hanya dikuasai oleh sekelompok kecil manusia saja. Melainkan harus berputar, didistribusikan secara adil hingga setiap individu memperoleh kesempatan untuk meningkatkan taraf hidupnya untuk menjadi manusia yang terhormat sesuai dengan harkat manusia sebagai wakil Allah SWT di muka bumi.

Instrumen distribusi pendapatan ini meliputi pertama, upah, yaitu mendistribusikan pendapatan melalui pola hubungan perburuhan. Kedua, zakat, infak, sedekah, yaitu memberikan sebagian kekayaan dari kelompok mampu kepada yang tidak mampu baik berdasarkan kewajiban (zakat) ataupun yang sunnah (infak, sedekah). Kemudian yang ketiga adalah waris dan wasiat. Keempat, adalah distribusi pendapatan melalui mekanisme pasar, yaitu dalam hal penetuan harga, larangan penimbunan, dan larangan berspekulasi. Yang kelima, yaitu distribusi pendapatan yang melalui pola kemitraan usaha yaitu akad kerja sama mudharabah dan musyarakah.

Instrumen-instrumen distribusi pendapatan inilah yang seharusnya diterapkan pada produk keuangan mikro syariah. Mengingat kondisi masyarakat miskin harus 
berurusan dengan kebutuhan sehari-hari, kondisi darurat yang bisa mempengaruhi kemampuan bayar sekaligus juga harus membiayai siklus kehidupannya, maka pendekatan secara berjenjang adalah hal yang tepat dilakukan. Artinya tidak semata-mata berorientasi profit melainkan lembaga keuangan mikro keuangan syariah tidak boleh kehilangan misi sosialnya. Ada masalah pada kaum miskin yang harus diselesaikan dengan zakat, infak, dan sedekah. Dimana bukan pinjaman yang diberikan, melaikan hibah sebagai bantuan social. Di jenjang berikutnya, ketika kondisi ekonominya sudah lebih baik, akad kerjasama mudharabah dan musyarakah bisa diterapkan.

Namun pada prakteknya lebih dari $70 \%$ produk pinjaman lembaga keuangan mikro syariah masih menggunakan akad Murabahah $^{6}$, yang dinilai lebih mudah diimplementasikan. Dari sudut pandang syariah, Murabahah merupakan salah satu akad jual beli yang halal dijalankan. Namun akad ini tidak menjamin pembiayaan yang dilakukan untuk tujuan produktif. Salah satu ahli keuangan konvensional menyatakan bahwa bank sebagai lembaga intermediary untuk menciptakan pertumbuhan perlu didorong untuk memberikan kredit yang digunakan untuk menciptakan barang dan jasa baru atau usaha produktif (Werner : 1992, 1997). Artinya jika lembaga keuangan mikro syariah memang menjalankan fungsinya sebagai intermediary, maka sepatutnya produk mudharabah dan musyarakah lebih dominan digunakan.

\subsubsection{Mengarahkan Lembaga kepada Kemandirian Keuangan (financial self sufficiency) dan Operasional (operational self sufficiency) dengan Meningkatkan Pemulihan Biaya (cost Recovery) dan Efisiensi serta Memperluas Jangkauan}

Kemandirian keuangan (financial self sufficiency) merupakan kondisi dimana suatu lembaga keuangan mikro tidak lagi tergantung dengan dana subsidi. Hal ini dihitung dengan menggunakan rasio kemandirian keuangan, yaitu rasio antara pendapatan dan biaya yang disesuaikan dengan tidak memperhitungkan faktor subsidi dan inflasi. Sedangkan kemandirian operasional (operational self sufficiency) adalah kondisi dimana suatu lembaga keuangan mikro mampu menutupi beban operasionalnya dengan pendapatan operasi. Dihitung menggunakan rasio kemandirian operasi, yaitu membandingkan pendapatan operasi dengan biaya operasi ditambah biaya pinjaman, dan biaya penyisihan piutang tidak tertagih. Jika suatu lembaga keuangan mikro tidak bisa mencapai kondisi mandiri operasional maka modalnya akan berkurang sebesar kerugiannya tersebut kecuali ada tambahan hibah yang diperoleh untuk menutupi kerugian tersebut. Artinya uang yang dapat digunakan sebagai pinjaman akan berkurang.

Kemandirian operasional merupakan indikator yang menunjukan stabilitas keberlanjutan keuangan lembaga. Tapi seperti juga ukuran keuangan yang lain, kemandirian operasional tidak menilai manfaat social baik yang dirasakan oleh nasabah, masyarakat, atau pun negara yang berkaitan dengan kesejahtaeraan dan pengentasan kemiskinan. Sejak era komersialisasi, kinerja keuangan dan keberlanjutan lembaga dalam sektor keuangan mikro sudah menjadi indikator yang penting untuk menarik tanggung

\footnotetext{
${ }^{6}$ Risk-sharing and Financial Inclusion : Foundations of Islamic financial Systems, September $22^{\text {nd }}$ 2011, dipresentasikan pada Seminar Keuangan Islam University of Durham. at the University of Durham's
} 
jawab social investor. Artinya, meski berpredikat sebagai social investor, namun orientasi untuk meraih profit ternyata juga menjadi penting.

Lembaga keuangan mikro kemudian menjadi ragu dan dipaksa untuk memiliki dua misi, yaitu misi sosial dan bisnis. Pada saat yang bersamaan, lembaga keuangan mikro harus mencapai tujuan dasar mengentaskan kemiskinan sekaligus juga harus mampu membangun sektor keuangan yang inklusif dengan memberikan akses keuangan kepada kaum miskin secara berkelanjutan. Hal ini kontraproduktif, karena untuk mencapai misi sosial dibutuhkan biaya yang tinggi. Lalu pada tingkat profit seperti apa yang harus dihasilkan untuk mampu menutupi biaya misi social ini, dan siapa yang harus menanggungnya.

Hal ini tentunya tidak adil bagi masyarakat miskin karena harus menanggung biaya operasional lembaga keuangan mikro melalui bunga pinjaman yang dibayar kembali bersama pokok pinjaman. Sebagai pihak yang seharusnya dibantu, masyarakat miskin justru harus membiayai usaha pengentasan kemiskinan dirinya dari kantongnya sendiri.

Dalam Ekonomi Islam, peran pemerintah disini menyentuh beberapa hal. Pertama menjaga agar tidak mengandalkan kekuatan pasar sepenuhnya. Disampaikan oleh (Naqvi : 2003) bahwa mekanisme pasar tidak dapat dibiarkan menjadi satu-satunya wasit dalam pengambilan keputusan ekonomi, melainkan harus dibatasi dan dipandu oleh nilai-nilai moral dan tujuan social. Seperti disampaikan pada jurnalnya (Abu Jouedeh : 2012) bahwa teori kurva permintaan dan penawaran tidak berlaku dalam kredit mikro. Secara umum, jumlah permintaan dan penawaraan suatu barang dan jasa akan dipengaruhi oleh tingkat harganya. Namun hal ini tidak berlaku dalam industri keuangan mikro yang berbasis bunga. Karena sering kali konsumsi atas keuangan mikro dilandasi atas keputusan yang tidak rasional yang diacuhkan sehingga mengarahkan kepada kondisi over-indebtedness. Tingkat harga dalam hal ini suku bunga pinjaman tidak lagi menjadi factor yang mempengaruhi keputusan dalam mengambil pinjaman. Karena meminjam sudah menjadi kebiasaan yang bersifat adiktif. Demikian pula dengan factor kemampuan membayar kembali (capacity repayment) tidak lagi menjadi factor yang menentukan bagi konsumen. Begitu banyaknya layanan keuangan mikro yang tersedia, membuat masyarakat memilki pilihan untuk membayar pinjamannya dari pinjaman yang lain bukan dari hasil usaha atau income-nya.

Kedua, melakukan perbaikan pada distribusi pendapatan yang adil, baik dengan bimbingan, pengaturan, maupun campur tangan langsung. Pemerintah harus mengembangkan iklim yang mendukung penerapan instrumen-instrumen distribusi pendapatan yang mampu mengentaskan kemiskinan baik itu yang sifatnya charity seperti zakat, infak, dan sedekah, serta yang sifatnya akad-akad perniagaan seperti mudharabah dan musyarakah.

Infrastruktur untuk menerapkan akad mudharabah juga harus dibangun. Selama ini lembaga keuangan mikro syariah kesulitan menerapkan akad ini karena masyarakat sulit menerima dan menjalankan bentuk kerja sama yang membutuhkan adanya keterbukaan antara pemilik dana dan pelaku usaha. Ditambah lagi, jumlah pembayaran kembali yang fluktuatif mengikuti keuntungan usaha, menyulitkan masyarakat miskin yang identik dengan pendidikan yang rendah. Maka perlu adanya edukasi-edukasi yang mampu merubah pemahaman dan meningkatkan keterampilan masyarakat untuk mengaplikasikan akad ini. 


\subsubsection{Menggunakan Sumber Dana Komersial}

Menggunakan dana komersial akan berimplikasi pada meningkatnya biaya operasional lembaga, yang pada akhirnya dibebankan kepada masyarakat miskin. Ketika masyarakat miskin tidak mampu mengembalikan jumlah pinjaman dengan bunga yang tinggi, lembaga keuangan akan mengalami kerugian, sehingga modalnya berkurang, dan kemampuannya memberikan pinjaman juga berkurang. Untuk menutupi kerugian, lembaga keuangan meminjam lagi dana komersial yang lain lagi sehingga bisa memberikan banyak pinjaman lagi, dan pendapatannya bertambah, dan begitu seterusnya.

Sehingga pertumbuhan kinerja keuangan lembaga keuangan mikro sama sekali tidak mencerminkan pertumbuhan usaha masyarakat yang merupakah sumber penghidupannya untuk keluar dari kemiskinan. Instrument mudharabah dan musyarakah dapat menjadi alat kendali pertumbuhan sektor keuangan yang seimbang dengan sektor riil. Lembaga keuangan mikro syariah dapat tetap mengakses dana komersial karena mudharabah dan musyarakah secara riil memberikan keuntungan dari hasil usaha yang dibiayai. Lembaga keuangan dapat mencapai tingkat kemandirian keuangan dan operasional, tidak tergantung dengan dana hibah pemerintah, dari bagi hasil usaha masyarakat. Maka keadilan akan tercipta, pertumbuhan lembaga keuangan mikro syariah menjadi cerminan tumbuhnya usaha masyarakat yang dilayaninya.

\subsubsection{Mendorong Lembaga Keuangan Mikro untuk Beroperasional Sebagai Lembaga Keuangan Formal yang Berorientasi Profit, yang Menerapkan Peraturan dan Prinsip Kehati-hatian, Sehingga Mampu Menarik Investasi Modal}

Menerapkan prinsip kehati-hatian merupakan bentuk tanggung jawab lembaga keuangan untuk menjaga keberlangsungan usaha. Dimaksudkan sebagai upaya memberi rasa aman bagi para investor, pemberi pinjaman komersial, maupun masyarakat yang menabung di lembaga keuangan mikro. Sehingga pada akhirnya ketika dana komersial banyak terhimpun maka lembaga pun mampu meningkatkan keuntungan dan jangkauan layanannya. Namun harus diingat bahwa disisi lain, penerapan supervise dan prinsip kehati-hatian dapat meningkatkan biaya operasional

Berdasarkan hasil Policy Research Working Papers The World Bank yang dipublikasikan Juni 2009 bahwa dari data 245 lembaga keuangan terbesar di dunia menunjukan bahwa penerapan prinsip prudential dan supervisi berbanding terbalik dengan profitabilitas lembaga. Analisa lebih lanjut menemukan bahwa lembaga keuangan mikro yang berorientasi laba menyerap biaya supervisi dengan membatasi jangkauan ke segmen pasar yang cenderung lebih mahal per dolar yang dipinjamkan. Artinya lembaga keuangan lebih banyak memberikan pinjaman kepada segmen dengan ukuran pinjaman yang lebih besar, sehingga biaya supervisi per pinjamannya menjadi lebih murah. Sebaliknya lembaga keuangan mikro yang bergantung pada sumber dana non-komersial atau dana hibah, dan kurang berorientasi pada laba, tidak menyesuaikan ukuran pinjaman (Cull : 2009).

Hasil penelitian tersebut memberikan gambaran, bahwa ketika lembaga keuangan mikro mau menerapkan prinsip kehati-hatian dan supervisi dalam rangka memperoleh profit, maka lembaga keuangan akan memprioritaskan misi bisnisnya dengan memberi pinjaman dengan jumlah yang lebih besar untuk menutup biaya supervise. Tapi jika pelaksanaan prinsip kehati-hatian dan supervisi tetap didukung oleh dana hibah, maka misi social akan tetap terjaga, karena lembaga tidak akan mengubah segmen pinjamannya. 


\section{F. Kesimpulan}

1. Komersialisasi pada lembaga keuangan mikro sebagai usaha untuk memberikan layanan keuangan kepada masyarakat miskin secara berkelanjutan dalam rangka mengentaskan kemiskinan tidak sepenuhnya bertentangan dengan etika bisnis Islam. Ada beberapa nilai yang sejalan dengan ajaran agama Islam seperti professional, mandiri, dan berkelanjutan.

2. Namun pada dasarnya konsep komersialisasi itu sendiri yang didengungkan akan mampu menggabungkan misi social dan misi bisnis bersifat kontraproduktif. Lembaga keuangan mikro akan mengalami kesulitan jika pada saat yang bersamaan harus mampu mengentaskan kemiskinan sekaligus menjadi lembaga berorientasi profit yang bisa memberikan keuntungan bagi investor.

3. Nilai-nilai moral dalam etika bisnis Islam yang menginginkan adanya keadilan dalam distribusi pendapatan dan kekayaan, apabila diimplementasikan dalam lembaga keuangan mikro syariah saat ini secara utuh justru akan mampu berperan dalam usaha pengentasan kemiskinan sekaligus meraih keuntungan secara wajar sebagai institusi bisnis.

\section{G. Daftar Pustaka}

Al Qur'an dan Terjemahannya, Kementrian Agama RI, PT Sygma Examedia Arkanleema

Bateman, M (2014). The Rise and Fall of Muhammad Yunus and The Microcredit Model. Saint Mary University

Bateman, M. Chang, Ha-Joon ( ) The Microfinance Illusion. University of Juraj Dobrila Pula, Croatia

Crane, Andrew,. Matten, Dirk. (2016). Business Ethics : Managing Corporate Citizenship and Sustainability in the Age of Globalization. Oxford University Press. United Kingdom

Cull, Rober,. Demirguc-Kunt, Asli,. Morduch, Jonathan. (2009) Does Regulatory Supervision Curtail Microfinance Profitability And Outreach? The World Bank, Washington DC

Joudeh, B. (2012). Exploring the Potential for Profit-Loss Sharing Modles in Islamic Microfinance. Huntsman Program Honor Senior Thesis.

Karnarni, Aneel (2007) Microfinance misses its mark, Stanford Social Innovation Review (Summer)

Lutzenkirchen, C. Weistroffer, C. (2012). Microfinance in evolution. An Industry between Crisis and Advancement. Germany : Deustche Bank Research

Levine. (2003). More on Finance \& Growth : More Finance, More Growth? Federal Reserve of St Louis

Membongkar Konsep Etika Bisnis Dalam Al Qur'an : Perspektif Epistemologis, Ahmad Syukron, MEI, STAIN Pekalongan

Nur Fadilla, Zulfa (2016) Mekanisme dan Sistem Distribusi Harta Perspektif Islam. Universitas Darussalam. Iqtishodia

Rutherford, Stuart,. Collins, Daryl,. Johnson, Susan. (2013) The New Microfinance Handbook, A Financial Market System Perspective - Client. Washington DC : The World Bank 
Scafer, Kai. Fukusawa, Yoshi. (2011) Factors Determining The Operational Self Sufficiency Among Microfinance Institutions. Midwestern State University

Stephanie Charitonenko and Ismah Afwan : Commercialization of Microfinance Indonesia. Asian Development Bank. 2003. Published by the Asian Development Bank, November 2003

Syukron, Ahmad (tanpa tahun) Membongkar Konsep Etika Bisnis Dalam Al Qur'an : Perspektif Epistemologis, STAIN Pekalongan

The Consultative Group to Assist The Poor. (2006). Good Practice Guideline for Funders of Microfinance. Microfinance Consensus Guideline. Washington : CGAP

The Consultative Group to Assist The Poor. (2010). Financial System Approach. Modul pada CGAP Funder Course, Bali : tidak diterbitkan

Naqvi, Syed Nawab Haider. (1993). Etika dan IImu Ekonomi : Sebuah Sintesis Islami, alih bahasa Husin Anis dan Asep Hikmat, (Bandung : Mizan, 1993)

Naqvi, Syed Nawab Haider. (2003). Perspectives on Morality and Human Well Being, A Contribution to Islamic Economics (United Kingdom : British Library Cataloguing, 2003)

Nawatmi, Sri. (2010). Etika Bisnis Dalam Perspektif Islam. Surabaya : Universitas Stikubank

http://pembangunaniesp.blogspot.com/2010/12/lingkar-setan-kemiskinan.html Lingkar setan kemiskinan dalam pembangunan dan cara memutuskan lingkar setan kemikinan. Diunduh 30 Juli 2018

http://www.economicsdiscussion.net/poverty/3-major-causes-of-vicious-circle-of-povertywith-diagram/4592 3 Major Causes of Vicious Circle of Poverty, Pragyandeepa, diunduh 30 Juli 2018

Mingka, Agustianto. (2013) Peranan Negara dalam Perekonomian (Perspektif Islam) www.agustiantocentre.com diunduh 8 Agustus 2018 